\title{
Vannak-e eredeti, új megoldások a latin-amerikai régió évtizedes problémáira? \\ Viták a fejlődés lehetséges útjairól
}

Gilles Carbonnier, Humberto Campodónico és Sergio Tezanos Vázquez (szerk.) (2017). Alternative Pathways to Sustainable Development: Lessons from Latin America. Leiden, Boston és Genf: Brill Nijhoff, Graduate Institute Publications. 344 o. https://doi.org/10.47707/Kulugyi_Szemle.2020.3.09

A genfi Felsőfokú Nemzetközi és Fejlesztési Tanulmányok Intézetének (a továbbiakban: Intézet) e kiadványa is jól illeszkedik az általuk korábban megjelentetett, regionális koncepció alapján szerkesztett (mint pl. Délkelet-Ázsiáról vagy a MENA-ról szóló) könyvek sorába. Nem véletlen, hogy az Intézet éppen a latin-amerikai régiót vette górcső alá, hiszen a térség az utóbbi évtizedekben - az úgynevezett pink tide időszakban és azóta is - különösen érdekes laboratóriumként működik, ahol az egyes országok eltérő politikai és gazdasági modellekkel kísérletezve próbálják a társadalmi-gazdasági problémáikat kezelni.

Latin-Amerika számos országában az 1980-as évek végétől - a diktatórikus rendszerek évtizedei után - demokratizálódási hullám söpört végig, ami a neoliberális gazdaságpolitikai intézkedések bevezetésével is együtt járt. Az átalakulás következtében a régió legszembetúnőbb problémái - mint az egyenlőtlenség és az informális gazdasági tevékenység - csak tovább növekedtek. Az 1990-es években azonban váratlanul drasztikus fordulat következett, a pink tide, amely során - egy-két ország kivételével - baloldali kormányok kerültek hatalomra, és egy teljesen más korszak kezdődött. E progresszív időszak alatt új szemléletű társadalmi-gazdasági modelleket alkalmaztak, amelyek az új évezred első évtizedére a demokratikus intézmények megszilárdulását, gazdasági növekedést, a szegénység csökkentését eredményezték.

A latin-amerikai társadalmakban új pozitív tendenciák, például a közösségalapú megoldások és a fejlesztés alternatív formái jelentek meg - olyan jelenségek, amelyek a jelenlegi tudományos vitákban is fontos témák, különös tekintettel a globális Délen megjelenő sajátosságaikra. Az ezredfordulót követő években a nemzetközi közösség által kitǔzött globális fejlesztési célok (millenniumi fejlesztési célok) több pontja tartalmazta a latin-amerikai régió kihívásait is, például az alapfokú oktatás egyetemes elérését, a nemek közti egyenlőség előmozdítását és a környezeti fenntarthatóság biztosítását. A számos globális kihívás közepette szükség van a politikai döntéshozóknak és a szakembereknek az új megoldások iránti nyitottságára, ahogy ez tapasztalható is volt a latin-amerikai térségben. 
A Carbonnier és társai szerkesztésében megjelent kiadvány célja a latin-amerikai és a karibi térségben a 2000-es évek elejétől bevezetett innovatív kísérletek narratíváinak, hatékonyságának és társadalmi hatásának a feltárása és összefoglalása. A könyv áttekintést és alapvető ismereteket nyújt a 21 . század első másfél évtizedének politikai, gazdasági, társadalmi és környezeti kérdéseiről, amivel nemcsak a latin-amerikai tanulmányokat gazdagítja, hanem hozzájárul a nemzetközi fejlesztési és posztfejlődési tanulmányokhoz is. A hasonló témájú tudományos munkák széles köréből kiemelkedővé és még relevánsabbá teszi, hogy a közölt írások, cikkek különféle múfajokat képviselnek: vannak köztük tudományos tanulmányok, interjúk és elemzések, valamint fejlesztési projektek értékelése is. Amilyen sokszínű a fejezetek szerzőinek a közössége (többségében a régióból származó tudományos kutatók, politikusok, fejlesztési szakemberek), olyan különböző tudományágakat - például közgazdaságtant, politológiát, szociológiát és jogot - képviselnek a munkáik is. A három szerkesztő maga is eltérő tudományterületeket, és kutatási központot képvisel. Gilles Carbonnier a Genfı Tudományos Intézet fejlődés-, gazdaságtan és humanitárius tevékenységének a professzora, Humberto Campodónico a DESCO szénhidrogén-ágazatának kutatója, Sergio Tezanos Vázquez pedig a nemzetközi együttmúködés professzora a Kantábriai Egyetemen, közös munkájuk révén így különböző szempontokat mutathatnak be a könyvükben.

A régió gazdasági, politikai és társadalmi tendenciáiról szóló tanulmányok eklektikus összeállítása három fő részre oszlik. Az első a fejlesztési narratívák részletes leírását tartalmazza, különös tekintettel az andoki régióra. A második a különféle stratégiák eredményeit és a külső befolyások szerepét vizsgálja, köztük a multilaterális fejlesztési bankok és a Kínából származó közvetlen külföldi tőkebefektetésekét. A harmadik rész bepillantást nyújt a társadalmi és a környezeti dinamikák sokféleségébe, amelyek bemutatása a kitermelő iparágak társadalmi hatásaitól a kontinenst sújtó erőszak témáján át a civil társadalom szerepéig terjed.

Az első fejezet a latin-amerikai gazdaságtörténet egyik ikonikus személyiségével, Fernando Henrique Cardosóval készített interjúval kezdődik, aki a régiónak a globális gazdaságban betöltendő jövőbeli szerepéről osztja meg a gondolatait. Cardoso, aki korábban Brazília elnöke és pénzügyminisztere is volt, munkásságával hozzájárult a régió gazdaságát leíró és évtizedekig meghatározó függőségelmélet (dependency theory) formálódásához (Cardoso és Faletto, 1969; Cardoso és Faletto, 1979). Munkáiban Cardoso már elhatárolta magát az 1960-as és 1970-es évek függőségelméletének mechanikai értelmezésétől, és a homogén perifériás meghatározással szemben a fejlődés különféle útjait hangsúlyozta. Szerzőtársával, Enzo Falettóval arra is rámutatott, hogy azokba be kell vonni a társadalmi és a politikai szereplőket egyaránt. Ennek a már általa korábban megfogalmazott nézetnek a bizonyítékai a könyv tanulmányai.

A kötet első részének egyik kiemelkedő fejezete az ún. good living (spanyolul: buen vivir, magyarul: jó élet) fogalmának a nagyon részletes, többoldalú megközelítésből 
történő bemutatását tartalmazza. Ez az egyedüláló ismertetés - amely a függőségelmélet óta először vonzza a társadalomtudósok figyelmét újra a régióra - alapos feltáró munka, átfogó bibliográfiai kutatás eredménye. A korábban megjelent tanulmányok (elsősorban a spanyol nyelvú irodalom) rendszerezése rávilágít a fogalom sokoldalúságára, számos kulturális alapjára, valamint az Andok és az Amazonas területén élő őslakos etnikai csoportok világképével való kapcsolatára. A szerzők megkülönböztetik a good living szemlélet három fő változatát (őslakos és pachamamist; szocialista és állami; ökológiai és posztfejlődési), felfedik a különböző intellektuális eredetüket, öszszefüggéseiket, hatásaikat és az egymással szembeni kritikájukat. Továbbá bemutatják a különféle társadalmi mozgalmak, a nemzetközi NGO-k, a politikai, értelmiségi és környezetvédelmi csoportok szerepét a koncepció kialakításának a folyamatában.

Mivel a könyv e része a régióban jelen lévő fejlesztési alternatívák panorámáját nyújtja, a szerkesztők egy-egy fejezetet szentelnek a jelenlegi, azaz a nyersanyagkitermelésre épülő fejlődési lehetőség, valamint az azt megkérdőjelező ún. posztkitermelői megközelítés bemutatásának. A két fejezetben megmutatkozó ellentmondás jól szemlélteti a régió jövőjével kapcsolatos - jelentősen eltérő - elképzeléseket, valamint azok különböző elméleti hátterét és az azokra épülő gazdasági stratégiák kialakításának a vitáit. Az egyik fejezet átfogó történelmi körképet nyújt a térségbeli - különös figyelemmel a közép-amerikai és karibi - nyersanyagalapú fejlődés alakulásáról, felvázolja az export diverzifikációjának a folyamatát és a természeti erőforrások árdinamikáját is. Ezt egy makrogazdasági elemzés egészíti ki, amely feltárja az egyes országok gazdaságának a sebezhetőségét és a hibás gazdaságpolitikai döntéseket, amelyek megakadályozták, hogy jobban kihasználják a 21. század első évtizedének az ugrásszerúen megnövekedett nyersanyagigényre épülő, kivételes időszakában rejlő lehetőségeket.

Alberto Acosta, a posztfejlődési iskola egyik kiemelkedő képviselője viszont a következő fejezetben megkérdőjelezi az állandó gazdasági növekedés szükségességét hirdetô, általánosan elfogadott elméletet és vele a természeti erőforrások iránti növekvő igény jogosságát (Gudynas és Acosta, 2011). Radikális elképzelései ismertetésével együtt feltárja a nyersanyag-kitermelésen alapuló gazdasági modell kritikus pontjait, egyben megkérdőjelezi a kapitalista rendszer alapjait is. A kritikái mellett javaslatot tesz arra is, hogyan lehet elkerülni az elsősorban a nyersanyag-kitermelő iparra épülő gazdasági modell csapdáját, megvalósítani a termelés-átalakítást, jobban kielégíteni az új társadalmi, politikai és környezeti igényeket, és e célok érdekében miként lehet átalakítani a hazai piacot. A kontinens jövőjéről szóló gondolat felvázolásából azonban hiányzik annak elemzése, hogy a latin-amerikai társadalom egyes rétegei hogyan viszonyulnak az általa felvetett fejődési lehetőségekhez, mik alkotják a radikális ötletek társadalmi alapjait, illetve az, hogy miképpen találnak egyensúlyt a szükséges kitermelői tevékenység és a vázolt alternatíva között. Írásában szorosan épít a good 
living tartalmára, és az új alternatív modell egyik fontos elemeként az ahhoz kapcsolódó szociális és szolidáris gazdaság szerepét hangsúlyozza (Coraggio, 2014).

A különféle fejlesztési narratívák bemutatása után a könyv második szakasza a már bevezetett stratégiák eredményeit vázolja fel, s azt a külső behatások - mint például a régió nyersanyag-kitermelő ágazatában érintett kínai beruházások és a multilaterális fejlesztési intézmények - szerepének elemzésével egészíti ki. E szakasz fejezeteit két részre lehet osztani: míg az elején az Andok térségének politikai és gazdasági folyamataiban bekövetkező változások következményeiről, a szegénység, az egyenlőtlenség, a földtulajdon, az őslakos népesség témaköreiről szólnak a tanulmányok, addig az utolsó két fejezet az egész régiót érintő folyamatok hatásait mutatja be. A pink tide (baloldali fordulat) korszakának az egyik legérdekesebb kérdése az, hogy azon országoknak, amelyek a "21. századi szocializmus” jelszavával hirdették meg a gazdasági-társadalmi átalakítást célzó, heterodox gazdaságpolitikai intézkedések bevezetését - pl. a Rafael Correa vezette Ecuador és az Evo Morales irányította Bolívia - milyen területeken és mennyivel sikerült jobb eredményeket elérniük, mint azoknak (pl. a szomszédos Kolumbiának és Perunak), amelyek a neoliberális gazdaságpolitika útján maradtak.

Az andoki régiót bemutató fejezetek egyike az összehasonlító módszertan segítségével elemzi a földtulajdonhoz való jognak, a földtulajdon koncentrációjának, valamint a mezőgazdasági termelési struktúrának, a földrajzi eloszlásnak, a termékeknek és a tulajdonjognak az egyes országokban a politikai folyamatok hatására bekövetkező változásait. A tanulmány feltárja a baloldali kormányok által alkalmazott politikai retorikában és programban kitúzött eredeti társadalmi és környezeti célok végrehajtásának a kudarcait az említett témakörökben. A földhasználat és a földtulajdon kérdése szorosan kapcsolódik a vidéki lakossághoz, különösen az őslakos közösségekhez, amelyek egyes andoki országok népességének a domináns csoportjait alkotják, és ezért következetességet jelent, hogy a kötet bemutatja e közösségek társadalmi-gazdasági helyzetét is.

Bár az országelemzések több szempontból aránytalanok, a szerző fő következtetése, hogy nincs jelentős különbség a két országcsoport által elért eredmények között - annak ellenére, hogy a célokat és azok megvalósítását a különböző politikai ideológiák alapján határozták meg. A gazdaságpolitikai és a szociális célok elérésének a lehetőségét jelentősen befolyásolják az érintett országok újraelosztási politikái, exportbevételei, valamint a nemzetközi piacoktól és a befektetôktől való függősége (a mezőgazdaság esetében főként a regionális transznacionális beruházók szerepe jelentős.). E megállapítások átvezetnek a következő fejezetekben tárgyalt témákhoz: a globális gazdaság - a kínai közvetlen tókebefektetések és a régióban múködő nemzetközi intézmények hatásainak a vizsgálatához.

1 A latifundium (nagy földbirtok) történelmileg beágyazott jelenség a latin-amerikai mezőgazdasági szektorban (Armendáriz és Larraín, 2017). 


\section{Külügyi Szemle}

Fontos megemlíteni a Latin-Amerika egyik legjellemzőbb problémájáról, az egyenlőtlenségről szóló fejezetet, bár mélyebb elemzés csak egyetlen országról, Peruról készült. E téma érintése nélkül nehéz elképzelni egy átfogó regionális gazdasági-társadalmi vizsgálódást, hiszen Thomas Piketty (2015) és mások munkái óta világszerte kiemelt figyelmet fordítanak erre a jelenségre (World Inequality Report, 2018), az ECLAC jelentései pedig mindig is rámutattak e problémára. ${ }^{2}$ Noha a fejezet elsősorban a szegénység csökkentésében elért perui eredményekre és az egyenlótlenségre összpontosít, a szerző nagyon részletes régióközi összehasonlító elemzést is nyújt. A tanulmány egyik különleges értéke, hogy a témát sokféle szempontból vizsgálja (pl. szociális programok, az állam szerepe az újraelosztásban, a munkaerőpiac, az egyenlótlenség érzékelése és a közvélekedés alapján), valamint széles adatbázist és különféle ökonometriai módszereket alkalmaz hozzá.

A könyv harmadik része a társadalmi és a környezeti problémákkal foglalkozik, amelyek az utóbbi évtizedekben Latin-Amerika népei számára és a politikai döntéshozatali folyamatok többségében egyre fontosabb kérdésekké váltak. A legsürgetőbb ügyek: az ásványkincsek fenntartható kezelése és annak jogi szabályozása, illetve intézményi keretének megteremtése; az erőszak megszüntetése és az állampolgárok biztonságának elérése; a társadalmi mozgalmak szerepe és befolyása.

A nemzetközi közösség az 1990-es évek óta egyre inkább tudatában van a fejlesztés és a fenntarthatóság közötti kapcsolatnak. A latin-amerikai régióban a fenntartható fejlesztési célok (Sustainable Development Knowledge Platform, 2015) és a bányászati tevékenységek összehangolása kulcsfontosságú, különös tekintettel a jelenlegi gazdasági és társadalmi kérdésekre. A cél eléréséhez hatékony, átlátható és részvételen alapuló intézményi rendszerre van szükség, amely az alkotmányos alapelvekre és jogi keretre épül. Az andoki alrégió országait összehasonlító fejezetek témái (pl. az etnikai csoportok jogai, a helyi érdekérvényesító képesség és a környezetvédelmi dimenzió) rámutatnak az intézmények kapacitásának megerősítésére irányuló komplex cél hatalmas kihívásaira, aminek az egyik pozitív következménye lehet a bányászati tevékenységnek a helyi fejlődést elősegítő hatása. A tanulmányból - a könyv korábbi fejezeteinek a tanulságaiba illeszkedően - kitúnik, hogy a decentralizáció, a kitermelő ipar, az etnikai csoportok jogai és a környezetvédelmi politika szempontjából nincs szignifikáns különbség a politikailag különböző ideológiát követő országok között.

Az erőszak és a búnözés magas arányának a következménye a közösségi kapcsolatok hálózatának a széthullása, ezért is különösen fontos egy, a társadalmi változásokat bemutató múben e súlyos problémának a taglalása. Az erről szóló fejezet számos nemzetközi intézmény adatai alapján nyújt átfogó összefoglalót. A fejezet szerzője arra

2 Az 1948-ban alapított Latin-Amerikai Gazdasági Bizottság (Economic Commission for Latin America and the Caribbean [2020], ECLAC; spanyolul rövidítése: CEPAL) az Egyesült Nemzetek Gazdasági Bizottságának az egyik szervezete.

Vannak-e ... új megoldások a latin-amerikai régió ... problémáira? 
mutat rá, hogy az elmúlt évtizedben új megközelítés alakult ki a búnözés elleni küzdelemben. Egyre több kormány veszi észre, hogy a tisztán elnyomó intézkedések alkalmazása nem eléggé hatékony, és mind fontosabbá válik a felelős állami hozzáállás és az állampolgárok aktivitása is a biztonság elősegítése érdekében. A tanulmány hiányossága viszont, hogy nem említi Juan Manuel Santos, a volt kolumbiai elnök kiemelkedő szerepét, aki az új szemlélet egyik jeles képviselője és előmozdítója volt. Az új megközelítés a büntetésjogi rendszer reformjában a megelőzést elősegítő tevékenységekre helyezi a hangsúlyt, különösen a kábítószer-háború következményeivel és az állampolgárok biztonságának megteremtésével kapcsolatban.

A záró fejezet két elemzést tartogat az olvasónak: az egyik a civil társadalomnak a "fellendülés évtizedében", azaz a megváltozott politikai és gazdasági helyzetben betöltött szerepéról szól, a másik a társadalmi mozgalmak új generációját mutatja be, a globális trendekkel összefüggésben. A társadalmi mozgalmak jelensége és aktív szerepe nem újdonság a régióban (Almeida, 2006), de a céljaik, az eszközeik (a közösségi média és a kommunikációs technológiák alkalmazása) és a jellemzőik megváltoztak. A társadalmi aktivitás és a részvétel új formációjának az egyik fő mozgatórugója a (valódi vagy az állampolgárok által érzékelt) kirekesztettség, az oktatáshoz, az egészségügyi szolgáltatásokhoz való hozzáférés és a döntéshozatali folyamatban való részvétel hiánya. Az évezred elején bekövetkezett gazdasági fellendülés hatására formálódó új középosztálynak - és a jogaik gyakorlásához tudatosan ragaszkodó attitúdjüknek - meghatározó szerepe van a mozgalmakban. A tanulmány értékét növeli az a tény, hogy számos, terepmunkával szerzett tapasztalatra, adatra épít, köztük a helyi civil társadalmi szervezetek munkájában való részvételre és a kulcsfontosságú szereplőkkel készített interjúkra.

A könyv széleskörúen merít a latin-amerikai valóság különböző aspektusaiból - a fejlesztési narratíváktól és stratégiáktól kezdve a jelenlegi társadalmi-gazdasági tendenciákig. Az olvasó egy jól szerkesztett, könnyen olvasható és alapos elemzésekre épülô tanulmánygyuujteményt kap, amely betekintést enged a térség gazdasági, politikai és társadalmi sajátosságaiba. A kötet minden egyes részében külön figyelmet szentelnek az andoki térség országainak: Kolumbiának, Ecuadornak, Bolíviának és Perunak. Ez a megközelítés pedig kiemeli a térségről szóló többi publikáció közül, hiszen a klasszikus politikai gazdaságtant és társadalmi kérdéseket felölelő múvek általában a régió erősebb gazdasági potenciállal rendelkező országait veszik górcső alá. Ugyanakkor a kötet szerzői valamennyi kérdéskört a térség egészének összefüggésében is megvitatják, és betekintést nyújtanak a megoldások sokféleségébe, nem csak az andoki régió jellegzetességeire. Az új évezred kihívásaira adott válaszok és megoldások között az egyik újdonság a good living fogalma és szemlélete (ideológiai háttere és gyakorlati megvalósítása), amely a könyv számos témáját érinti. 


\section{Külügyi Szemle}

A kiadványt az átfogó szemlélete teszi alkalmassá arra, hogy a társadalomtudományok különböző ágait képviselő kutatók számára is értékes információforrást jelentsen. Kifejezetten ajánlható nemcsak a latin-amerikai régióra specializálódott, de a nemzetközi fejlesztés szakterületén tanulmányokat folytató posztgraduális és doktoranduszképzésben részt vevő hallgatók, valamint az érintett területek kutatói számára is. A könyv értékes elemzései és eset- és országtanulmányai az elméleti szakértők mellett különösen hasznos tudnivalókkal szolgálnak a politikai döntéshozók, jogászok és a nemzetközi fejlesztési ügynökségek szakemberei számára is.

Deák Ágnes

\section{Irodalomjegyzék}

Almeida, Paul és Johnston, Hank (2006). Latin American Social Movements: Globalization, Democratization, and Transnational Networks. Lanham: Rowman \& Littlefield Publishers.

Armendáriz, Beatriz és Larraín B. Felipe (2017). The Economics of Contemporary Latin America. Cambridge, MA: MIT Press.

Cardoso, Fernando Henrique és Faletto, Enzo (1969). Dependencia y desarrollo en América Latina: ensayo de interpretación sociológica. Mexikóváros: Siglo Veintiuno Editores.

Cardoso, Fernando Henrique és Faletto, Enzo (1979). Dependency and Development in Latin America. Berkeley, CA: University of California Press.

Coraggio, José Luis (2011). Economía Social y Solidaria: El trabajo antes que el capital. Quito: Editorial Abya-Yala.

Economic Commission for Latin America and the Caribbean (2020). About ECLAC. A letöltés ideje: 2020. szeptember 17. https://www.cepal.org/en/about.

Gudynas, Eduardo és Acosta, Alberto (2011). La renovación de la crítica al desarrollo y el buen vivir como alternativa. Utopía y praxis latinoamericana 16(53). 71-83.

Piketty, Thomas (2015). A tőke a 21. században. Budapest: Kossuth Kiadó.

Sustainable Development Knowledge Platform (2015). Transforming Our World: the 2030 Agenda for Sustainable Development. A letöltés ideje: 2020. szeptember 17. https://sustainabledevelopment.un.org/post2015/transformingourworld.

World Inequality Report (2018). Executive Summary. A letöltés ideje: 2020. október 19. http://wir2018.wid.world/executive-summary.html. 